\title{
The EU-NATO Syndrome: Spotlight on Transatlantic Realities
}

\section{Hajnalka Vincze}

\begin{abstract}
This article examines the relations between the European Union (EU) and NATO in light of both of the current, deeply unhealthy, state of the transatlantic relationship, and of its ongoing evolution. The first part is devoted to a retrospective outline of the links between European defence and the Atlantic system, which highlights the major constant features of these last sixty years, as well as the rupture points. Then, various issues, from the problem of the division of labour and the definition of the chain of command to coordination on the ground and arms procurement, are evoked as concrete examples where the same fundamental question marks emerge, again and again; all of them revolving around the concept of sovereignty - that of the Europeans vis-à-vis America. It is suggested in the article that current European dependence does not allow but superficial and/or temporary 'progress' in EU-NATO relations, just as is the case in the broader Euro-American relationship. As long as Europeans will not assume fully the objective of autonomy (i.e. freedom of decision and action, with all the commitments it would imply), their subjection will continue to generate increasing tensions, since this inherent imbalance is not only detrimental to Europe's own interests, but it also excludes any reciprocity and prohibits any genuine partnership with the United States.
\end{abstract}

CONTRARY TO THE TWO DOMINANT, ALBEIT DIAMETRICALLY OPPOSED, TYPES of forecasts that were both highly fashionable a few years ago, it appears more and more clearly that the headaches related to the EU-NATO conundrum are here to stay. Those who, in view of the initial difficulties of establishing mutually acceptable relations between the two organizations, were talking about teething problems likely to be replaced, in due course, by a harmonious insertion of the new-born European Security and Defence Policy (ESDP) into the Atlantic system, were just as wrong as those who saw in it yet another occasion to toll the death knell of the North Atlantic Alliance. As it is, neither of the two scenarios seems close to becoming a reality any time soon.

The reason is very simple: transatlantic relations have arrived at a stalemate point. A crucial, though precarious, moment of balance, characterized by the fact that the United States is no longer able to prevent Europe from gradually moving towards more independence, while the Europeans are not yet ready to fully achieve their emancipation. In EU-NATO terms, this equation is reflected, on the one hand, by the US incapacity to block the launching of European defence within the frameworks of an organization of which they are not part (the EU), and on the other, the attachment of Europeans to the upholding of an organization (NATO) that institutionalizes their subjection to American pre-eminence in the security field.

This article proposes to focus on relations between the EU and NATO, by highlighting the political interests and strategic designs which determine progress or, most of the time, the blockages and pseudo-progress one can witness there. Indeed, two problems, closely related to one another, come out as the bottom-line from any analysis, whether it bears on the European integration or NATO, or a fortiori on the relations between the two. The first one is linked to the nature and general evolution of the transatlantic 
relationship, the second to the modalities of various integration mechanisms. For the European countries, when it comes to their relations with the United States, these two problems appear in limpid terms: dependence versus autonomy, and integration versus sovereignty. The key aim of this article is to raise and to decipher these stakes such as they appear in the different fields (institutional contacts, cooperation on the ground, planning, capabilities, assigned missions and procurement) of the relationship between NATO and the EU. In order to better put the subject into its context, the first section is devoted to the relations between the Atlantic Alliance and European defence before the latter was taken charge of in the EU framework, notably with the launching of ESDP in June 1999. After the enumeration of the major issues around which all initiatives and debates are articulated as from this date, the article will finish with an outline of what could be deemed the only scenario which, on both a strategically realistic and democratically legitimate basis and under radically different conditions from those experimented until today, could guarantee a lasting preservation of the transatlantic partnership.

\section{Brief survey of the past}

By way of introduction, some defining elements in the historical context of the current EU-NATO relations will be underlined. However, before this is possible, it is important to make a clear distinction between structural continuities and the circumstantial variables. Seen under this angle, it is clear that neither the election (and re-election) of George W. Bush, nor the terrorist attacks of 11 September 2001, nor the war against Iraq, constitute a breaking point in transatlantic relations. Their impact is of another nature. These events did nothing but reinforce and/or accelerate major tendencies which had already been at work for a very long number of years. But especially, as a result of their broad mediatisation, they brought them into daylight, lifting the lid on the opaque universe of the taboos and 'non-dits' (things unvoiced and unspoken of) which has been, for decades, that of the interactions between Europe and America. Finally, as for the two moments which mark the only genuine ruptures in the transatlantic relationship throughout the last sixty years - namely the end of the bipolar era and the launching of a European defence policy within the frameworks of the EU - even at these times it proved to be impossible to completely neglect the weight of continuity. If the first fracture (end of the "cold war") spectacularly transformed the external and internal conditions of EuroAmerican relations, it was necessary to wait for ten years before the Europeans started, in particular with the launch of ESDP, to draw the first tentative conclusions.

\section{Pre-history of EU-NATO relations}

Since the end of the Second World War, each decade has seen at least one (failed) attempt from the European side of the Atlantic Alliance to develop a more or less distinct profile in security matters. For example, George Bidault and Ernest Bevin in vain pondered, in 1947, a Western Union in which 'Western Europe should be independent both of the United States and the Soviet Union' (Howorth and Keeler 2004: 6). The Six ${ }^{1}$ in vain wanted to think about a so-called European Defence Community (Communauté européenne de défense or (ED) in the 1950's, and the Fouchet Plans of the 1960's proposed in vain an intergovernmental union with its own defence policy. ${ }^{3}$ Similarly,

\footnotetext{
1 The founding members of the European Coal and Steel Community (ECSC or CECA): France, Germany, Belgium, Luxemburg, Netherlands, Italy.

${ }^{2}$ Treaty establishing the European Defence Community, signed in Paris, on 27 May 1952, rejected by the French National Assembly, on 30 August 1954.

${ }^{3}$ Draft Treaty - Fouchet Plan I (2 November 1961) and Draft Treaty - Fouchet Plan II (18 January 1962).
} 
those who had meanwhile become the Nine, ${ }^{4}$ launched in vain their European Political Cooperation (EPC), with the idea that 'the close ties between the United States and Europe of the Nine do not conflict with the determination of the Nine to establish themselves as a distinct and original entity' (EC 1973)..$^{5}$ Then in the 1980's, Europeans also in vain resuscitated the Western European Union, by stating that 'the construction of an integrated Europe will remain incomplete as long as it does not include security and defence' (WEU 1987). Before 1989, any aspiration of this kind was, from the start, condemned to fail. During the 'cold war' era, it was simply unthinkable to treat defence issues within a strictly European framework. Europe's subordination to American leadership was regarded as self-evident, and the rule was thus crystal-clear: when speaking about Europe, one cannot even think 'defence' and when speaking about defence, one cannot even think 'European'.

To illustrate this, one episode which arguably is the most frequently quoted and distorted, can be mentioned - the failure of the Treaty establishing the European Defence Community. This treaty which was rejected in 1954 by the French National Assembly is like a concentrate of the constraints which governed the relationship between 'European' defence and the Atlantic system throughout the bipolar period, at the same time as a precious display of the correlations between supranational integration and European dependence. To summarize these stakes, it is enough to recall the objection made by General de Gaulle, who fiercely opposed the treaty. To him, 'the CED consists in gathering European forces to collectively place them at the disposal of the United States'. ${ }^{6}$

Indeed, parallel to provisions of a supranational character applying to the Six (majority voting, common budget, training and armament programmes etc.), article 18 of the treaty stipulates that NATO's supreme commander (i.e. the commander-in-chief of the US armed forces in Europe) 'is entitled to make sure that the European defence forces are organized, equipped, trained and prepared in a satisfactory way'. For that, they 'receive technical directives' from the Atlantic Alliance. 'As soon as they are ready to be employed, they are assigned to the supreme commander' of NATO, who uses them to his own discretion, except when there is unanimous opposition of the Six (article 77) and this in peacetime. In wartime, the US General automatically exerts 'the full powers and responsibilities of supreme commander'. It is not surprising that De Gaulle believed that 'this army called "European"', à la CED, would have been nothing else but 'one of the instruments of American strategy'. The mere fact that the CED project is still remembered and referred to as the pre-figuration of what could have been a 'European army' explains a lot about the confusions and/or manipulations around the label European.

\section{Some constant features}

According to Lawrence S. Kaplan (2004: 130-131) in transatlantic relations "plus ça change, plus c'est la même chose" (the more things change, the more they stay the same)'. Kaplan goes on to suggest that 'almost from the inception of the alliance, Europeans have sought to get out from under American domination and chafed at their

\footnotetext{
${ }^{4}$ The six founding members, plus the United Kingdom, Denmark and Ireland, who entered the European Economic Community in 1973.

${ }^{5}$ It's worth noting a slight difference between the French and English versions of the text : in the French document, the ties between Europe and America "do not affect" the Europeans' determination to affirm themselves, whereas in the English version those same ties "do not conflict" with this European aspiration.

${ }^{6}$ De Gaulle's speech at the French National Assembly, 26 October 1950, available at:

http://www.gaullisme.fr
} 
inability to free themselves'. Actually, the various attempts at "emancipation" were condemned to fail, as far as they remained within the logic of an original paradox: Europeans hoped to build an independent profile in security and defence matters without touching anything in the transatlantic relationship, based on their dependence in this field and on the imbalance thus created. This leads us to elicit two persistent aspects of the last half-century of Euro-American relations, (1) a succession of psychodramas and (2) a structural American interest (as opposed to the circumstantial European one) perpetuating this situation of imbalance.

With regard to the constant tensions between the two sides of the Atlantic, the remarks of Harold Brown, President Carter's former Secretary of Defense, summarise rather appropriately the general ambiance: 'They tell me the Alliance is in disarray. When has it ever been in array?' (Heisbourg 1987). In terms of obvious disagreements between allies, we are, indeed, spoilt for choice. The crisis of Suez in 1956, the British trauma following the abandonment of the Skybolt project by the USA in 1962, the withdrawal of France from the integrated structures of NATO in 1966, the dissensions around the Vietnam war, the 'détente' policy vis-à-vis the Soviet Union, or president Reagan's 'Star Wars' initiative are but the tip of the iceberg (see Kaplan 2004; Hendrickson 2007). The crises, omnipresent, were overcome only because quite palpable interests worked in this direction. On the European side, these were, in the wake of the Second World War, objective interests, which have become, with time, subjective interests stemming from a mix of institutionalised de-responsibilisation, deeply anchored reflexes of subordination, and the lack of political will to free themselves from dependence links that are unworthy and prejudicial but, in the short run, often very comfortable.

On the US side, the approach is much more 'Cartesian'. Keeping the European continent under American control is a geo-strategic interest that largely transcends the circumstances of certain moments in time (see Layne 2006). It is, in addition, spiced up by the compensations Europeans agree to pay in exchange for what is customarily called the 'protective umbrella'. In these two respects, some official US documents speak for themselves. In 1992, the Pentagon's confidential Defense Planning Guidance, whose extracts were diffused in the press and stirred up a mini-storm among European allies, contended that America needs to 'discourage' the advanced industrial nations 'from challenging our leadership or seeking to overturn the established political and economic order', as well as to 'maintain the mechanisms for deterring potential competitors from even aspiring to a larger regional or global role' (Gellman 1992). One year after, the Bottom-up Review of the new Clinton administration explained how those who are thus kept under control are even expected to pay for being kept under control: 'Our allies must be sensitive to the linkages between a sustained U.S. commitment to their security on the one hand, and their actions in such areas as trade policy, technology transfer, and participation in multinational security operations on the other'?

\section{Proto-history of EU-NATO relations}

Under these conditions, one understands more easily the importance of the rupture brought about by the collapse of the bipolar system, depriving US domination in Europe of its apparent justification or raison d'être. By the same token, one also understands more easily the nervousness of US officials at the time. The administrations of George $\mathrm{H}$. Bush and William (Bill) Clinton ceaselessly repeated that Washington's European commitment went well beyond the Soviet threat, and that the United States remains a European power. Nonetheless, the circumstances of the exercise of this power had been changed, and irreversibly so.

\footnotetext{
${ }^{7}$ Report on the Bottom-up Review, Les Aspin, Secretary of Defense, October 1993.
} 
With the end of the Cold War, one observes simultaneously an intensification of the inherent tensions of the transatlantic relations, and the disappearance of the massive external threat which was formerly essential to mask them and/or contain them at an acceptable level. The United States, suddenly finding itself to be the only one standing in the arena, was most of all concerned with perpetuating its position of force. On the other hand, Europeans, engaged for decades in a gradual process of integration in which it became more and more difficult to neglect security and geopolitical aspects, found themselves confronted with a sudden and spectacular extension of their theoretical margin of manoeuvre. This resulted in a structural opposition, which would be manifest above all in the heated controversies on the issue of European defence.

Consequently, 'as the United States perceived the increased momentum towards European agreement on a defence identity early in 1991, a number of alarm bells were rung by US officials' (Sloan 2000). In the long series of more or less muffled warnings, one should note 'a closely-held memorandum sent to European governments by UnderSecretary of State for International Security Affairs Reginald Bartholomew in February 1991', which 'according to published reports...expressed concern that the United States might be "marginalised" if greater European cohesion in defence led to the creation of an internal caucus within NATO'.8 And, at this moment, there was only question of possible a European caucus inside NATO...

Be as it may, the new Treaty on European Union was a masterpiece of the so-called 'constructive' ambiguity. ${ }^{9}$ It maintained European defence in uncertainty between a European and an Atlantic rationale, by establishing the bases of a 'common foreign and security policy including the eventual framing of a common defence policy, which might in time lead to a common defence', but by taking care to define a double role for the WEU: 'the military arm' of the European Union was in the same time 'the European pillar' of the Atlantic Alliance. This floating of the WEU between the two institutions was meant to delay a delicate face-to-face with the most sensitive issues. In particular the one related to knowing whether European defence was going to be implemented within an autonomous European framework (EU) or in a logic of subordination, under American control and leadership (NATO). In order to tip the scales in favour of the second option, the United States was forced to give successive concessions. They had to bow to the idea of a European 'caucus' inside the Alliance, with the recognition of the ESDI, based on the principle of 'separable but not separate' European capacities (see Kaplan 2004: 109-128; Howorth 2000). However, as it turned out, it was but a short reprieve.

Apart from the structural determinants, three major factors were combined during the 1990 's to lead the Europeans, largely despite themselves, in a European direction. The Balkan conflicts brought a clear demonstration, if ever needed, of the disadvantages of being at the mercy of a third party, even if it is a friend and ally. The AFSOUTH episode (American refusal to cede even one regional NATO command to a European) was revealing of American will to perpetuate their undivided control, and it confronted the Europeans, once again, to the realities of their junior partner status. Finally, the hasty and profound reorganisation of the US defence industry landscape added to all this the fear of a pure and simple absorption of the European defence technological and industrial base. It is not by chance that the new EU treaty, signed in 1997, finally started to outline

\footnotetext{
8 Guicherd, C. (1991) 'A European Defense Identity: Challenge and Opportunity for NATO', Congressional Research Service Report, Washington, 12 June 1991, pp. 57-61. Referred to by Sloan (2000).

${ }^{9}$ Treaty on European Union, signed in Maastricht on 7 February 1992, entered into force on 1 November 1993. See Official Journal C 191, 29 July 1992.
} 
the path towards the solution. ${ }^{10}$ It spoke about 'progressive' instead of an 'eventual framing of a defence policy' which, furthermore, 'will be supported, as Member States consider appropriate, by cooperation between them in the field of armaments'. Even more importantly, it introduced the idea of the 'possibility of the integration of the WEU into the Union, should the European Council so decide'. To the general surprise, it was a thing done, hardly more than a month after the entry into force of the Amsterdam Treaty.

\section{The rupture}

The breakthrough occurred in December 1998, with the Franco-British agreement of Saint-Malo, ${ }^{11}$ and was officialised within the framework of the Fifteen at the June 1999 summit of the EU Heads of State and Government. ${ }^{12}$ Thanks to a spectacular British reversal (London lifted the veto which it opposed throughout the Amsterdam negotiations) the question of European defence would have, from now on, to be tackled on radically new bases. The former NATO dogma was to be replaced by an EU-NATO cohabitation. The WEU's relevant functions were to be integrated into the EU. The Alliance's dead-born ESDI had to cede the place to the EU's new security and defence policy (ESDP).

The importance of these changes can hardly be overestimated. In the words of Richard Hatfield, Policy Director at the UK Ministry of Defence, the removal of the British veto 'let the genie out of the bottle'.13 This it did, despite the fact that, in the new constellation, the protagonists wanted to pursue their own respective agendas, which remained as antagonistic as before. For Great Britain, the key was to keep the Atlantic Alliance alive, notably with an improvement of European capabilities likely to interest the Americans, even if one needs, for this purpose, to accept that a European defence policy be launched within the EU. For France, on the other hand, it was a question of taking the first decisive step towards Europe's emancipation, even if this came with the price of making some necessary gestures designed to reassure Washington (see Howorth 2005).

The extent of the rupture was reflected in the delay the Americans took to fully realise what was happening. Officials and diplomats on the other side of the Atlantic persisted during months, sometimes even years, to confuse European security and defence "identity" and "policy" (see Albright and Cohen 2000). Given that the first one had been conceived within NATO in a logic of maintaining US control, and precisely in order to avoid the second being ever launched, the jury was out on whether the confusion was due to deliberate arrogance, wishful thinking or mere ignorance of developments on the old continent. Be as it may, certainly not everybody missed the point. As Peter W. Rodman (1999) observed as early as November 1999 at a congressional hearing:

This EU effort to construct a separate European defense identity comes three years after NATO adapted its own procedures to recognize and promote a European Security and Defense Identity within the Alliance framework. The new EU procedure, in contrast (at least in some Europeans' minds), will enable Europe to dispense with the Americans, "if it wishes". That seems to be, indeed, its whole point.

\footnotetext{
${ }^{10}$ Treaty of Amsterdam amending the Treaty on European Union and the Treaties establishing the European Communities and related acts, signed on 2 October 1997, entered into force on 1 May 1999. See Official Journal C 340, 10 November 1997.

${ }^{11}$ Franco-British Summit Joint Declaration on European Defence, Saint-Malo, 4 December 1998.

${ }_{12}$ Presidency Conclusions, Cologne European Council 3 and 4 June 1999.

${ }^{13}$ Richard Hatfield, The Consequences of Saint-Malo, Public Lecture at IFRI, Paris, 28 April 2000. Quoted in Howorth (2000).
} 
The future Assistant Secretary of Defense for International Security Affairs ${ }^{14}$ could not have been more right.

\section{Major issues}

Instead of going through the period since the launching of the ESDP in a chronological order, this article adopts a thematic approach because the various subjects of controversy which, after 1999, had marked various moments of EU-NATO relations do still remain, in one way or another, a potential source of tensions. Indeed, none of the issues in question has found a lasting solution and so long as the fundamental conditions of the transatlantic relationship do not change, it is unlikely that a lasting solution will be found. Given the limitations of length, each area is to be presented very briefly, with the emphasis placed on the central contradictions governing its evolution. ${ }^{15}$

\section{Main actors}

Henry Kissinger's famous question 'If I want to find out what Europe thinks, whose telephone number do I call?' summarises perfectly the (slightly condescending) stereotype that sees the fundamental difference between America and Europe in the distinction between a unified and homogeneous US power, as opposed to European fragmentation. One should, however, nuance this truism. On the one hand, those who know Washington well also know that the rivalries, turf battles, blame games, and diverse pressures result in a complex and opaque universe, the study of which shows a strange familiarity with the Kremlinology of the Soviet era. On the other hand, the European fragmentation is not a deficiency per se. As Christopher Patten, former EU Commissioner for External Relations put it, 'What matters most is not whether there are several telephone numbers but whether there is a similar response or message from whoever is on the line' (Patten 2005: 159). It is on this point that one observes a marked difference between two sides of the Atlantic as soon as it comes to the essential questions related to the very foundations of the Euro-American rapports de force. Here, as a response to Washington's consequent line, followed with determination and steadiness for sixty years, the only European answer is the diametrically opposed visions of EU member states, most of them being unable to come to terms with the concept of power and/or that of autonomy.

From Washington's part, the most natural attitude vis-à-vis any ambition towards a genuine European independence is to oppose it. Obviously, it is much more comfortable to have, as allies, interlocutors with no real bargaining power and no real alternative. Hence the usual motto: the United States expects from Europe 'complementarity with, but not autonomy from, America' (Brzezinski 2004: 106). NATO remains one of the best instruments to achieve this, which explains the efforts deployed by Washington to preferably prevent, or at least to lay down strict conditions for, the launching of European defence (see Howorth 2007: 136-146). It was, indeed, the sense of Madelaine Albright's famous 3Ds criteria right after Saint-Malo: 'no decoupling, no duplication, no discrimination'. In other words, European decision-making should not be

\footnotetext{
${ }^{14}$ On July 12, 2001, the Senate confirmed Peter W. Rodman as Assistant Secretary of Defense for International Security Affairs.

${ }^{15}$ The particular issues dealt with under this chapter have been studied in detail by the author in EU-NATO relations: between necessary cooperation, inherent competition and the inescapable change of paradigm (manuscript for the book "Az Észak-atlanti Szerződés Szervezete a változás korában", SVKK, Budapest, 2005), available at www.hajnalka-vincze.com/Publications/119. Also, further readings with ample details on the subjects in question will be indicated in the footnotes as a substitute for developing the factual-chronological aspects in the present paper.
} 
unhooked from a broader Alliance decision-making, ESDP should not duplicate resources and assets which already exist in the Alliance, and ESDP should not discriminate between European members of NATO according to their membership or not in the European Union. The three were, of course, in obvious opposition with the inherent logic of a European defence. The fact remains that the typical 'arguments' (i.e. accusations of anti-Americanism and friendly warnings against the waste of resources), regularly called upon to initially avert or, if it fails, to contain within precise boundaries any inclination towards European autonomy, are employed today to guide the evolution of ESDP towards a model as close as possible to the original 3Ds.

However, besides the politically unacceptable character, for Europe, of these US designs, America's behaviour with regard to the Alliance complicates day after day the task of those in Europe who oppose the idea of autonomy. Indeed, Washington's attachment to the preservation of NATO (as the instrument of US influence and control in Europe) is hardly coupled with actual American gestures attesting their commitment to this same NATO. Be it the (very) low level of US participation in NATO operations on the ground, the non-observance by America itself of NATO standards and norms, or the US preference for more flexible ad hoc coalitions, rather than the constraints of the Alliance, the result is the same outcry of despair in (Euro-)Atlanticist circles: 'Look, I am all for NATO, but if the Americans are not, what am I to do?'16 In addition, the little sensitivity of the Bush administration to the well-established transatlantic face-saving games, has exposed even more clearly both the scale and the downsides of European subordination.

Not being able here to explore the details of the EU the Member States' individual attitudes, ${ }^{17}$ only one recent conclusion drawn by Jolyon Howorth (2007: 160) is evoked:

Almost all EU member states, whatever their initial point of departure in relation to the complex issue of relations between NATO and ESDP, tend recently to have shifted somewhat in their institutional preferences. The shifts mainly involve slight moves reflecting waning (but by no means expiring) enthusiasm for NATO and growing (but by no means overwhelming) enthusiasm for ESDP.

But, above all, it is to be stressed that these shifts are far from modifying the basic context, which is that of reluctance, or even outright hostility of the large majority of the EU Member States vis-à-vis the idea of a genuine emancipation of Europe. This internal opposition comes from naive pacifism and/or servile Atlanticism. Two equally irresponsible and ultimately fatal attitudes, both a testimony to the European elites' chronic inability to grasp the fact that (1) refusal of power leads to powerlessness and (2) refusal of independence leads to dependence. Powerlessness and dependence means no credibility, therefore no negotiating position whatsoever on any issue of significance, be it the course of world events, the development of the transatlantic dialogue or the mere defence of European interests (see Vincze 2006).

In practical terms, this fundamental intra-European division has several major consequences. Firstly, regarding the Alliance; the proponents of European autonomy need NATO, at least temporarily and even in its current asymmetrical shape, to ensure the mobilisation of the majority of the EU governments with regard to favouring the development of European assets. It is, in a sense, considered as a useful framework for an upgrade by stealth of European capabilities.

\footnotetext{
${ }^{16}$ Dominique Moïsi quoted in Friedman (2002).

17 On European approaches to the NATO-ESDP relationship, see Howorth (2007: 146-160). For a comparison of the two major - British and French - models, see also Part 3 (Highest stakes) of the present paper.
} 
Secondly, with regard to ESDP; decision-making at 27, on the basis of the lowest common denominator inevitably leads to a diluted defence policy. Even though the project to set up a certain kind of European military capability is no longer in question, it is its very heart which, for the time being, is lacking (nuclear deterrence, explicit mandate for territorial defence, military space policy and related common programmes), and its essential conclusions which still remain to be drawn (for instance, making the safeguarding of the European technological and industrial base a political obligation, via the institution of a 'European preference').

Thirdly, on the course of European integration in general; in these circumstances, practically each 'step ahead' in the integration of the 27 is like an additional fastener on a straitjacket. Without a radical change of direction, based namely on a general awakening to the notion of sovereignty and the stakes involved, any push towards 'communautarization' would do nothing but lock Europe even more in a definitive position of dependence. As for the solution, it has been floated for ages. According to the new French Minister of Defence, 'European defence cannot be realized with twentyseven countries. It will be constituted on the basis of a core group of states manifesting the will to embark on this process, and we will find in this core the countries engaged in the European construction for the longest period of time'. ${ }^{18}$

\section{Hierarchy and division of labour}

One of the most heated debates of EU-NATO relations has been articulated, from the very beginning, around the concept of non-decoupling, which, in the US reading, should mean that NATO decides first to respond or not to a particular crisis situation. Whereas some Europeans would not find a priori anything wrong with such a formal sequencing, for others it is politically unacceptable, insofar as it would enclose European defence in a subcontractor role. The controversies revolve around the established formula used in ESDP documents: 'where NATO as a whole is not engaged'. In reality, however useful they were in order to overcome initial opposition, these few words will always remain subject to divergent interpretations. As a NATO Assembly report noted in 2005: 'The US takes the view that [this formula] gives NATO the first right to consider a military operation. The EU could undertake operations only after 'NATO as a whole' has decided not to be engaged. The EU, on the other hand, has not recognised that right for NATO' (Minniti 2005).

These 'misunderstandings' were most manifest during the discussions, in 2005, on how to respond to the African Union's request for help in Darfur, when the US administration 'argued that NATO should take the lead and the EU should stay out' (Keohane 2006). In the end, the two organisations ended up conducting two parallel operations. But already at the first EU-only military mission (Operation Artemis in the Democratic Republic of the Congo, in June 2003), the thorny issue of hierarchy gave rise to diverging accounts: 'EU statements assert that NATO was regularly 'informed' of EU intentions in Bunia. NATO officials counter that 'informing' them after the fact does not equal "consultations"' (Michel 2004: 91). Lord Robertson, for his part, preferred to underline that 'NATO did not want to participate....' ${ }^{19}$

Be as it may, not only does the problem remain unsolved (the EU Parliament's recent note on EU-NATO relations talks of 'lingering controversy' over the question of 'sequencing' (Cornish 2006: 11-12), but it is even bound to take on new forms. For

\footnotetext{
18 Hearing of French Defence Minister Hervé Morin before the National Assembly's National Defence and Armed Forces Committee, 4 July 2007. On linkages between European sovereignty and multiple-circle integration scenarios, see Vincze (2006b).

${ }^{19}$ NATO Notes, vol. 5 (6), 6 June 2003, Center for European Security and Disarmament.
} 
instance, it remains unclear which organisation would have priority in using doublehatted forces (designated both for the EU and NATO) to address an emerging security challenge. In any case, the official texts do not explicitly codify any kind of sequencing or hierarchy between NATO and the EU. As France is always keen to point out, neither to NATO's nor to the EU's advantage, EU-NATO cooperation is 'fully respecting each organization's decision-making autonomy. So there is no right of first denial, on either side'. $^{20}$

The issue of hierarchy is closely linked to that of the so-called division of labour. An allegedly clear picture of this latter is reflected in early EU documents, such as the landmark Cologne Presidency Conclusions that see NATO as the foundation of the collective defence of its members' and the EU concentrating on Petersberg-type crisis management tasks. ${ }^{21}$ However, there are, and have been from the outset, several problems with this tempting but overly simplistic idea. On the EU side, apart from the fact that the higher end of the Petersberg missions is a grey area, responsibility for collective defence, in some form or another, is less and less easy to be kept away from ESDP. ${ }^{22}$ On NATO's side the collective defence guarantee has never been a very convincing one. US refusal to commit to anything resembling an automatic defence of European allies led to a carefully crafted text in the Washington Treaty, in which the famous pledge (Article 5) leaves individual member states free to fashion their response to an attack according to their respective national interests (Kaplan 2004: 2-5).

Characteristically, Article 5 tends to be deformed nowadays into an argument for raising European troops to shoulder US forces engaged in external operations, and lifting the national caveats placed on their use under US/NATO command. This shift in the interpretation of 'solidarity' is in line with the general evolution of the Alliance, depicted by Howorth (2003: 15) as 'an organisation which is transforming itself from one whose original purpose was to deliver US engagement in the cause of European security into one whose new purpose is to deliver European engagement in the cause of US global strategy'.

That is how, right from the beginning of the 1990's, NATO turned to crisis management missions, complying with the famous US warning 'out of area or out of business'. Today, a new direction has been fixed (by the Americans, of course). It is time to break out of the yoke imposed by the basically military nature of the Alliance and head, without further delay, towards civilian dimensions. Namely the ones they pick and choose as being of particular interest. NATO's Secretary General was rather clear in this respect: 'In the age of globalisation, virtually any societal problem can quickly escalate into a security challenge. So it is hardly surprising that pundits are constantly calling on NATO to go global, and add every new emerging challenge to its already crowded agenda. In some cases they are right'..$^{23}$

Parallel to the multiplication and expansion of the overlaps between NATO and EU competence areas, numerous ideas were put forward to delineate the two organisations, on either a functional or geographical basis. Whereas the proposals to establish some

\footnotetext{
${ }^{20}$ Guide to the European Security and Defence Policy (ESDP), Permanent Representation of France to the European Union, November 2006, p.12.

${ }^{21}$ Following the WEU's Petersberg Declaration of June 1992, these are described in Article 17.2 of the current EU Treaty as "humanitarian and rescue tasks, peacekeeping tasks and tasks of combat forces in crisis management, including peacemaking".

${ }^{22}$ As seen during the negotiations of the so-called constitutional treaty, or most lately in Article 27.7 of the Draft Treaty amending the Treaty on European Union and the Treaty establishing the European Community.

${ }^{23}$ Keynote speech by NATO Secretary General Jaap de Hoop Scheffer at the Riga Summit, 28 November 2006.
} 
kind of 'division of the world' between the EU (in charge of Africa for example) and NATO (more interested in Asia) are of a doubtful connotation and had but very little resonance, those that would give the 'high-end' missions to NATO and the 'low-end' (in the mud) operations to the EU seem (slightly) more popular, but just as unrealistic.

First, such codification of the respective tasks is unacceptable from the European point of view. It is, for one thing, reminiscent of a long-standing unease within the Alliance over the distribution of roles between US and European forces. As the historian Kaplan (2004: 6) explains, already during the development of the first strategic concept, in 1949, 'the allies were discomfited by the recognition that they would serve as cannon fodder in the event of a Soviet attack. American airmen in the skies above the battle would be less subject to casualties than the European troops on the ground below. Echoes of dissent over this division of military labor could be found a half century later in Kosovo and Afghanistan'. Also, attempts to define a clear functional division of NATO and EU missions hide, in a not very subtle way, the willingness to confine ESDP to civilian crisis management (especially policing and reconstruction) tasks. This could be construed as somewhat absurd knowing that for General Sir Rupert Smith (former Deputy SACEUR) for instance, 'Europe is the best weapon to win both war and peace' (Smith 2005).

Even more importantly, any formal division of labour is unimaginable for the simple reason that both organisations are determined not to give up any competence segment. No wonder that NATO's Deputy Assistant Secretary General disagrees openly with those who 'say the best way to avoid any clashes or competition between NATO and the EU would be sort of to divide up the world into zones', and thinks that 'there is nothing to stop either organization being involved anywhere in the world, so we should not have artificial geographic divisions'. To those who 'say there should be a functional division of labour, that NATO would do the hard security missions and the EU the soft security missions', Mr. Shea's answer is that 'we shouldn't try to sort of put organizations into compartments'. ${ }^{4}$ Indeed, it is more than clear that both organisations are adamant on keeping all options open, and hence consider any formal division of labour politically unacceptable.

\section{Forums of consultation}

Usually, commentators like to note that with 32 countries being represented altogether in the 26-member NATO and the 27-member European Union, relations between the two organisations are to a large extent, relations between the same set of countries. If it is to highlight the alleged nonsense of the difficulties in inter-institutional dialogue, the remark can be misleading, insofar as it is precisely this remaining 'small' difference between the two membership lists that explains the scope of the difficulties. Difficulties that, at first glance, seem to be of a technical nature and related to the non-EU member NATO country Turkey (see Howorth 2007: 167-170), but which are but a disguise for the real difficulties, this time of a politico-strategic character and linked to the relationship between Europe and America.

As from the starting point of 1999, it is the United States who had established the requirement of non-discrimination against European members of NATO outside the EU, as part of the 3D-conditionality for ESDP. Encouraged by this US support, Ankara (and with it, although in a less vehement way, the other European non-EU NATO members) insisted, taking pretext of their Alliance membership, on exerting a considerable influence in the new decision-making structures of ESDP. Behind this, the real question was, once again, that of the NATO's primacy and the EU's subordination to it. However,

\footnotetext{
${ }^{24}$ Video lecture by Jamie Shea, Deputy Assistant Secretary General for External Relations, 12
} February 2004. 
whereas the disputes delayed the launching of the operational phase of European defence (suspended, for political reasons, to an EU-NATO agreement alternately blocked by Turkey and Greece), at the same time they highlighted the potential for serious blackmail, and thus paradoxically provided an incentive to the EU to move towards autonomy from NATO.

Today, after the EU enlargement in 2004, the roles are in a sense reversed, since the problems are linked now to non-NATO member EU countries. But the basic conundrum remains the same. On the surface, we find again a Turkish veto: Ankara refuses to allow sensitive information to be exchanged with the EU as a whole, and Cyprus and Malta in particular, at joint meetings (they being neither members of the Alliance, nor participants in Partnership for Peace which would allow some intelligence sharing). For its part, Cyprus, adamant on preserving its status as an equal member of the EU, has prevented the rest of the EU from engaging in broader discussions with NATO. This technical stumbling block (which is, of course, alimented by Turkish grievances vis-à-vis a not-so-welcoming EU and the unresolved status of the Cyprus issue) created a stalemate. The agenda of formal meetings between the two institutions are limited to issues relating to 'Berlin Plus' operations (those being carried out by the EU with recourse to NATO assets), with non-participating Cyprus and Malta being subsequently informed. As a result, though formal EU-NATO meetings are held at various levels, their agenda is as narrow as possible, and though informal meetings have been set up to circumvent the formal constraints, these are without an official agenda and without any information to parliaments (see Hofmann and Reynolds 2007; Shimkus 2007).

Rather tellingly, the EU and NATO paint two very different pictures on the state of their relationship. EU Presidency reports on ESDP give a factual, overall positive assessment of cooperation between the two organisations, whereas NATO officials have been incessantly calling publicly for a deeper and extended dialogue with the EU suggesting that the problem runs much deeper than the sole Turkey issue. In fact, however serious the political motivations are behind Ankara's technical objections, they are nowhere near to the structural-strategic considerations for which the Cyprus deadlock is a mere smokescreen. As Norway's NATO delegation put it: 'some EU member states prefer to limit cooperation in order to preserve the EU's character and decision making autonomy and to fend off US influence on European policy'. ${ }^{25}$

In the words of Jaap de Hoop Scheffer, 'some deliberately want to keep NATO and the $\mathrm{EU}$ at a distance from one another. For this school of thought, a closer relationship between NATO and the EU means excessive influence for the USA. Perhaps they are afraid that the ESDP is still and too new and vulnerable for a partnership with NATO'. ${ }^{26}$ Notwithstanding the last remark, with its strange ambiance of a kindergarten beauty contest, concerns about undue American influence are, indeed, at the heart of the matter. But when 'French officials sometimes say that close EU-NATO relations could lead to the US gaining excessive influence over EU foreign and defence policy' or that 'the US may use NATO missions as a means for getting European troops to serve American strategic interests', even the UK based Centre for European Reform has to conclude that these 'French fears about US priorities are not completely unfounded' (Keohane 2006: 2).

If Paris is wary of discussing far-reaching policy issues within US-dominated NATO, Washington is no less cautious about dealing with its European allies outside this thoroughly controlled framework. No wonder that another venue for transatlantic get-

\footnotetext{
25 Norway's perspective on NATO-EU cooperation, Norway's Permanent Delegation to NATO, January 2007.

${ }^{26}$ NATO and the EU: Time for a New Chapter, Keynote speech by NATO Secretary General, Jaap de Hoop Scheffer in Berlin, 29 January 2007.
} 
togethers, namely the official EU-US summits have so far touched only timidly on security issues. As noted in a Congressional Research Service Report, 'US officials are concerned that a wide-ranging or formal strategic dialogue with the EU could ultimately erode NATO, where the United States has not only a voice but also a vote' (Archick 2005: 3). And not only 'a vote'; as the editor of the Atlantic Monthly put it: 'NATO is ours to lead, unlike the increasingly powerful European Union' (Kaplan, R.D. 2005). By the same token, he pointed out the fundamental constraint in EU-NATO relations: 'Let me be even clearer about something that policymakers and experts often don't want to be clear about. NATO and an autonomous European defense force cannot both prosper' (Kaplan, R.D. 2005). Indeed, NATO as the instrument of US control over Europe is, by definition, incompatible with European autonomy.

\section{Headquarters and command}

One of the focal points of US concerns has been to torpedo any attempt at establishing a European military Headquarters and an all-EU chain of command (Larrabee 2004: 59). In fact, due to 'skilful British negotiation in the early days of ESDP, when a compromise was forged that left a specific gap in the chain of command for EU-led military operations and linked their planning to NATO capabilities' (Goerens 2006), the mandate of the EU Military Staff was restricted, from the outset, to strategic planning. ${ }^{27}$ Consequently, there is no complete and permanent European chain of command, and no capacity to plan an operation without having recourse to NATO's planning capabilities or a national Headquarters. However, this shortcoming is merely the result of a political choice, and as such has never been set in stone.

Indeed, the so-called 'Chocolate Summit' in April 2003 between French, German, Belgian and Luxembourg leaders put the idea forward in an open and allegedly provocative way. As their joint declaration stated, 'we propose to our partners the creation of a nucleus collective capability for planning and conducting operations for the European Union'. ${ }^{28}$ The initiative met with massive hostility (at best the timing, one month after the start of the US invasion of Iraq, was generally considered most unfortunate, at worst it fuelled already virulent Francophobia in some Atlanticist circles), and, as usual, was consensually dismissed as a spectacular failure. For a failure, it was certainly one that its initiators would gladly repeat any time. In fact, by the end of the same year the long-awaited breakthrough had been achieved at the all-EU level. The document European Defence: NATO/EU Consultation, Planning and Operations, adopted by the European Council in December 2003, created the basis for an EU CivMil Cell, which might become, one day, a genuine EU Headquarters. Of course, it did this in an extremely cautious way, by sugarcoating the controversial measure with the simultaneous establishment of an EU cell at SHAPE and the invitation of a NATO liaison team at the EU Military Staff (to facilitate the conduct of Berlin Plus operations), and by specifying that for the conduct of autonomous EU military operations the first option remains the use of national HQs multi-nationalised for the occasion. But there is, definitely, a possibility of a collective European capacity, even if it is to be called upon especially when no national $\mathrm{HQ}$ is identified, and when a joint civilian/military response is required. In those cases the EU CivMil Cell would 'have responsibility for generating the capacity to plan and run the operation' not from a standing HQ but from an Operations Centre rapidly set up on a case-by-case basis. ${ }^{29}$

\footnotetext{
${ }^{27}$ Council Decision of 22 January 2001 on the establishment of the Military Staff of the European Union (2001/80/CFSP).

${ }^{28}$ Meeting of the Heads of State and Government of Germany, France, Luxembourg and Belgium on European defence - Joint declaration, Brussels, 29 April 2003 ("Tervuren Declaration").

${ }^{29}$ For a description of the EU OpsCenter history, concept and implementation, see Stephen Pullinger (2006).
} 
In view of the number of precautions taken, most commentaries anticipated a civilian profile for the new structure: 'perhaps the real added value of the Cell's OpCen would be for it to be operationalised to oversee and manage civilian crisis management operations whilst military operations appear most likely to draw upon NATO's assets and capability under Berlin Plus arrangements or, in the case of autonomous EU operations, upon the five identified national HQs' (Pullinger 2006: 18). ${ }^{30}$ However, it is not what the entire logic of the Cell's establishment was about. In fact, the first OpsCenter activation occurred through the EU's second specifically military exercise (MILEX 07, from 7 to 15 June 2007) (EU 2007: 5). Furthermore, the recent agreement on a new chain of command for civilian ESDP operations, with the establishment of a Civilian Planning and Conduct Capacity (CPCC) (EU 2007: 6) might also indicate that the OpsCenter is unlikely to be confined to a solely civilian crisis management role.

Of course, these developments are not met with universal acclaim. It is not a coincidence that new counter-propositions are emerging, such as calls for NATO-EU joint planning. This new ingenious approach aims to strip the Union's OpsCenter of much of its substance, while harnessing, to NATO's benefit, the EU Commission's long-coveted civilian resources in an oblique way. According to the director of the Transatlantic Relations Program at ACUS (Atlantic Council of the United States), the EU liaison cell at SHAPE and the NATO team at the EU Military Staff 'instead of serving merely as liaisons' should 'become the beginning of a modest planning staff', which 'should also include representatives from the European Commission, so that the Commission's considerable expertise and resources devoted to reconstruction and development can be included in this effort' (Burwell 2006: 94-97).

\section{Berlin Plus and operations}

Today the scenario in which the EU conducts an operation with recourse to NATO assets is implemented on the basis of the so-called Berlin Plus arrangements. ${ }^{31}$ Their origins go back to the 1996 NATO Ministerial in Berlin, where foreign ministers agreed to make NATO assets available for EU-led operations. At the 1999 Washington Summit this provision was extended for EU-led crisis management operations under ESDP, but it was not before December 2002 that the modalities were approved in a political document called NATO-EU Declaration on ESDP.

\footnotetext{
${ }^{30}$ The five pre-identified national HQs are those in France (Mont Valérien), Germany (Potsdam), the UK (Northwood), Greece (Larissa) and Italy (Rome).

${ }^{31}$ According to the Alliance's fact sheet: the "Berlin Plus" arrangements adopted on 17 March 2003 following the political decision of December 2002, provide the basis for NATO-EU cooperation in crisis management by allowing EU access to NATO's collective assets and capabilities for EU-led operations. They consist of the following major elements: a NATO-EU Security Agreement (covers the exchange of classified information under reciprocal security protection rules); assured EU access to NATO's planning capabilities for actual use in the military planning of EU-led crisis management operations; presumed availability of NATO capabilities and common assets, such as communication units and headquarters for EU-led crisis management operations; procedures for release, monitoring, return and recall of NATO assets and capabilities; terms of reference for NATO's Deputy SACEUR - who in principle will be the operation commander of an EU-led operation under the "Berlin Plus" arrangements (and who is always a European) - and European command options for NATO; NATO-EU consultation arrangements in the context of an EU-led crisis management operation making use of NATO assets and capabilities; incorporation within NATO's long-established defence planning system, of the military needs and capabilities that may be required for EU-led military operations, thereby ensuring the availability of well-equipped forces trained for either NATO-led or EU-led operations. (see http://www.nato.int/issues/nato-eu/evolution.html)
} 
Of course, these agreements do not resolve all questions, far from it. For a start, the Berlin Plus package has never been made public or transmitted to the national parliaments for ratification. Even more significantly, the so-called guaranteed access is, by its nature, hypothetical and as such, subject to the particular situation and the political will. For Kori Schake, professor at the US Military Academy at West Point and former director on the National Security Council, '[a] real assurance of availability would mean that the EU's crisis-management priorities would take precedence over the other global responsibilities and interests of the United States. Assured access is a faulty premise even for some NATO operations, much less for those in which the Unites States is not directly involved' (Schake 2003: 117). ${ }^{32}$

Nonetheless, according to the usual formula reiterated in the EU Presidency reports on ESDP: operational 'EU-NATO co-operation in the context of the 'Berlin Plus' arrangements has continued to work smoothly and efficiently'. The sentence refers to EU operations in the Balkans, which so far constitute the textbook cases of Berlin Plus implementation (Masson 2006), namely Operation Concordia in Macedonia taking over NATO's Allied Harmony mission in March 2003 (Vincze 2003) and Operation Althea launched in December 2004 to replace NATO's SFOR in Bosnia-Herzegovina (EU 2007: 16-17). Despite official praises of an exemplary cooperation between the two organizations, frictions and hurdles were actually not uncommon before, during and after the launch phase of these operations. As noted in the NATO Parliamentary Assembly's latest report, 'on-the-ground achievements were not as institutionally seamless as might have been thought. Indeed, the success of the handover evidently depended heavily on the commanders on the ground from both organizations, who were forced to de-conflict what evidently were sometimes unclear and overlapping mandates' (Shimkus 2007).

Moreover, new operational configurations may put Berlin Plus under increasing pressure. After the already mentioned Darfur dispute (Monaco and Gourlay 2005: 3-5), the recently launched civilian EU mission in Afghanistan (EU 2007: 10-12) and the planned operation in Kosovo (EU 2007: 12-14) might put EU-NATO arrangements to the test again, for various reasons. There are, in fact, reports on proposals within the Alliance to opt for the Berlin Plus scenario even in situations where both organisations are deployed in the same theatre but conducting different operations, such as it is and might be the case in Afghanistan and Kosovo. This view, strongly voiced by Turkey, is 'based on the claim that since NATO clears the theatre for an EU police mission to enter, the EU ultimately relies on NATO assets and capabilities' (Hofmann and Reynolds 2007: 6). Kosovo could also create another precedent - as signs of US interest in participating in a prospective ESDP civilian mission are growing stronger. Washington would certainly be very attentive to the security needs of American personnel, and might be tempted to use it as a pretext to define/re-define the respective authorities of the two organisations in favour of reinforcing NATO oversight.

\section{Capabilities and armaments}

Just like in any other dimension of EU-NATO relations, in the capabilities field too, debates and actual developments revolve around the issue of European autonomy. As George W. Bush's former director on the National Security Council observed; 'Without having genuinely autonomous military forces, Europe's needs are subordinated to US priorities. The EU is left hostage to the concerns and potential veto of the United States...' (Schake 2003 : 130). At the level of the units, it is above all the famous issue of

\footnotetext{
32 During President George W. Bush's first term, Schake was the director for Defense Strategy and Requirements on the National Security Council. She is at present a research fellow at the Hoover Institution.
} 
hierarchy and sequencing that re-emerges, while at the level of equipment, it is the American postulate of non-duplication which is in question. To sort out these thorny issues, the NATO-EU Capability Group, which met for the first time in May 2003, is expected to achieve consistency between the European Capability Action Plan (ECAP)/Capability Development Mechanism (CDM) and NATO's Prague Capability Commitment (PCC), as well as between the NRF (NATO Response Force) and the EU Battlegroups. In fact, at present a coordinated rotational schedule makes sure that no member's units will be serving in both forces simultaneously. It remains, however, unclear which organisation would have priority in using the forces designated for both of them or whether the current de-confliction will hold for airlift and other enabling capabilities; let alone the problem of 'cream-skimming' (concern that NATO will cream off the best forces for its own use, leaving the ESDP with second-rate capacity), or that of the NRF's still vague role and functions.

In any case, the new NATO force is unanimously regarded as the catalyst for transformation', a capability modernisation process carried out under the direction and control of ACT (Allied Command Transformation - one of NATO's two strategic commands, the other one being responsible for operations). This is a process based on a paradigm with, so to speak, a strong American inspiration. Located at Norfolk (in Virginia), ACT is in the immediate vicinity of the US Joint Forces Command facilities, which undoubtedly is a practical solution, given that the Supreme Allied Commander of ACT is at the same time the Commander of United States Joint Forces Command (USJFCOM).

As for the 'equipment' part of the capability development problem, whereas European insufficiencies in certain key areas are hardly in doubt, the question to be asked when procuring defence material (besides the technical specifications in the definition of which it would be preferable to have a say) is to know from where it comes and who is in control. The issue of control of the availability of the material is closely related to that of sharing of sovereignty. The project to pool 3 or 4 Boeing C-17 between 15 Member States of NATO (neither France, nor Germany, nor Great Britain are part of it) is illustrative of the integrationist approach. Resistances to it come primarily from two sources.

First, the big countries (those who up to now took care to preserve, to various degrees, the range of capabilities necessary to their autonomy of decision-making and action) prefer to keep control over their assets. In addition, among the small states, naturally more attracted to common solutions, there are some (i.e. Belgium) who say that once it comes to sharing sovereignty, it is better be within a European framework. Indeed, since most European States are also NATO members, the capabilities they jointly acquire reinforce the Alliance automatically. In particular, the chances to keep (a share of) real control are incomparably less in an Alliance de facto dominated by the Americans than in a Europe where power relations are more balanced, regulated and institutionalised, and strategic interests and preferences are somewhat closer to each other.

The origin of the equipment matters above all with regard to the security of supply, and the potential of pressure and blackmail which it may imply. At this point, it might not be completely uninteresting to recall that, in NATO, the Assistant Secretary General for Defence Investment has always been a US national. It is not a coincidence that, as we have seen, one of the motivations behind the launching of ESDP was the safeguarding of the European defence industrial and technological base. Similarly, 'US fears, immediately after Saint-Malo, focused on the EU's potential to rival the USA in military hardware. This fear was not unconnected with the other ambition expressed in the Saint-Malo Declaration: "a strong and competitive European defence industry and technology"' (Howorth 2007: 139). 
Traditionally, European purchases of US armament occur on the basis of a 'two-way street' philosophy. Already in the years 1960-1970, 'the principal American arguments in this debate concerned the reductions of costs linked to a limitation of duplications within the arms production for NATO, and the military advantages of a standardisation of materials; but the underlying reasoning has always been related to cost sharing and a compensation for US military expenditure in Europe' (Ellner 2004: 126). In fact, Washington wanted to achieve a 'more equitable sharing of costs', and the proposed remedies involved, among other things, greater purchases of US military equipment. (Kaplan 2004: 51-52). The danger, for Europe, has always been to see her autonomy undermined at its very foundation, at the level of technology, armament production and control over their most elementary or sensitive defence capabilities. The British model is indicative of the risks, as Tony Edwards, former Head of UK Defence Exports (1998-2002) pointed it out: 'The UK maintains its capability to project power by an extraordinary reliance on the US for technology, equipment, support and intelligence'. ${ }^{33}$

In Washington, European efforts to preserve and shape autonomous capabilities are denounced as anti-Americanism and 'disparaged as a waste of funds, when US capabilities could be relied on or purchased' (Adams et al. 2004: 154). According to an academic report (Adams et al. 2004: 116-117) carried out under the aegis of the Center for Technology and National Security Policy of the US National Defense University, today 'Europeans have three options for arming national or cross-national forces with modern defense technology'. They can acquire advanced technology from the United States, or develop defence systems and technologies on a transatlantic basis, but in these cases they have to be aware of the detrimental consequences of buying American for the European industrial and technology base. 'Third, the Europeans could strengthen their own defense industrial and technology base, both to supply their own defense technology independently of the United States, and to provide partnership and competition with US companies. There has been considerable and growing support in Europe for this third option over the past decade. (...) The decision to create the EDA may represent a critical breakthrough in this process' (Adams et al. 2004: 116-117).

In fact, the role of the European Defence Agency cannot be taken for granted in this respect and will depend on the policy pursued by its 26 participating states (all EU countries, except Denmark). ${ }^{34}$ In particular on their readiness to acknowledge the necessity of a specifically European approach to the armaments issue (see Vincze 2006c, 2006d). Back in 2004, Nick Witney, head of the European Defence Agency (EDA) said that the EDA plans 'should eventually include a buy-European preference' (Tigner 2005). In December 2006, the director of EDA's Industry \& Market Directorate, observed that a common European vision should involve, inter alia, 'less dependence on non-European sources of supply'. He is right. He is also right to note, about the stakes involved, that 'at root, it is to do with independence, sovereignty and autonomy' (Hammarström 2006: 11).

\footnotetext{
${ }^{33}$ Contribution on the Commission's Green paper by Tony Edwards, quoted in The European defence equipment market: Article 296 of the Treaty establishing the European Community and the European Commission's Green Paper, report submitted by Franco Danieli, at the Assembly of the Western European Union, 6 December 2005. Tony Edwards is former Head of the UK's Defence Export Services Organisation (1998-2002), Visiting Professor at The Royal Military College of Science and has retired recently as Chairman of The Air League.

34 The European Defence Agency was established under a Joint Action of the Council of Ministers on 12 July, 2004, "to support the Member States and the Council in their effort to improve European defence capabilities in the field of crisis management and to sustain the European Security and Defence Policy as it stands now and develops in the future". One of its ascribed functions is to create a competitive European Defence Equipment Market and strengthen the European Defence, Technological and Industrial Base.
} 


\section{Highest stakes}

Behind the imbroglio of EU-NATO relations, and at the heart of what is traditionally called the transatlantic misunderstandings, one finds a systemic tension between the two sides of the Atlantic; on the one side, an American ambition aiming at a total and overall control (a mixture of the traditional quest for 'absolute security' (Chace and Carr 1988) and the, by the way completely natural, desire to maximize and perpetuate their acquired positions and advantages) and, on the other hand, Europe's fundamental interest (more or less assumed, depending on the actors, the issues and the moments) to preserve or, if necessary, to acquire freedom of decision and action. According to John Van Oudenaren (2003), director of the European section of the US Congress Library, America is today the classical 'status quo' power of the international system, while Europe is the most revisionist of all the actors on the world stage. The first strives to sustain its hegemonic position, while the second constitutes, insofar as it assumes an (increasingly more) autonomous existence, an undeniable challenge to America's dominance.

As we have seen through the particular subjects, this power struggle is articulated around a fundamental alternative which appears mainly on two plans. Firstly, that of integration ('pooling' under the aegis of the Atlantic system or safeguarding of the national margins of manoeuvre), and (2) that of autonomy (reinforcement or reduction of European dependence). The arguments for the (Euro-)Atlanticist option (pooling within the Atlantic structures, locking Europe in a situation of dependence) are the same in both cases; it seems enough to invoke the miracle words of 'efficiency' and 'pragmatism', to justify short-sighted and fundamentally irresponsible choices. All the more irresponsible, is that the victims of this first scenario would also be the same Europe's sovereignty and, with it, the very possibility of a transatlantic relationship based on genuine partnership.

\section{Integration}

Integration within the NATO system raises some important questions that have not changed since the time when France had put them forward to justify her withdrawal from the integrated military structures. First of all, there is a substantial distinction to be made between the Atlantic Alliance, brought into being by the 1949 Washington Treaty and the integrated military structures created later within its framework, i.e. the North Atlantic Treaty Organisation (NATO). For example, although they remained members of the Alliance, Greece (1974-1980), Spain (1986-1997) and France (from 1966) were not part of the integrated military structures. According to the French Foreign Minister's speech in 1966; 'One is in no way the condition for the other, even if, in current terminology, and through an ambiguity perhaps intentionally maintained, the term "NATO" covers both the Alliance and the Organization'. The latter is essentially 'a whole group of integrated international commands, placed unavoidably under the authority of the strongest, by far, of all the partners'..$^{35}$

The French objections at the time against the integrated NATO system were of three types, relating in particular to its anachronism, the de-responsibilisation which it entails

\footnotetext{
${ }^{35}$ Maurice Couve de Murville, French foreign minister, speech to the French National Assembly, April 14, 1966. The distinction is well reflected even in the title of one of the "recommended books" on NATO's homepage, notably "L'Alliance atlantique et I'OTAN, 1949-1999: un demi-siècle de succès (dir. Pierre Pascallon), Bruxelles, Bruylant, 1999". See www.nato.int/issues/faq/index.html. The present article follows the - erroneous but established - practice of using the two terms as if they were interchangeable, except on those instances when the distinction is most directly relevant to the issue being treated.
} 
and the fact that it undermines sovereignty. Already by 1966, the circumstances had radically changed compared to the years when Europe was in ruins and the United States the one single power with an atomic bomb. The countries of Western Europe had recovered to the point of becoming America's trade competitors. The Soviet Union, having entered what would become the nuclear club, was able to strike the United States directly, which seriously called into question the credibility of US commitment for the protection of Europe. In addition, America's unilateral military activism, with its potential of general escalation, raised the level of risk to Europe, insofar as its strategy in NATO merged with that of the USA, to be involved in the fight 'even if she did not wanted it'. ${ }^{36}$ Military integration 'under the leadership of a partner infinitely more powerful than the others" also encourages a free-rider attitude, by depriving the governments and populations of the sense of their responsibilities in defence matters. ${ }^{37}$ Subjection and the de-responsibilisation it provokes are especially incompatible with the right to self-determination and the will to preserve an autonomous capacity of assessment, decision and action.

If the reasoning is today as topical as ever, it is because US control over NATO is still just as unquestionable and its consequences for Europe still just as pernicious. One telling example is that of NATO's command structure. In order to ensure a complete unity of command, from the Pentagon down to allied activities on the ground, the Supreme Allied Commander Europe (SACEUR), who is the head of Allied Command Operations located at SHAPE, Mons, Belgium, is no other than the U.S. four star general heading U.S. European Command (U.S. EUCOM) located in Stuttgart. Also, the chief of Allied Forces South Europe (AFSOUTH) headquartered in Naples is at the same time the US commander in charge of US Naval Forces in Europe, belonging directly under US EUCOM. As such, it is not surprising that French attempts to secure the AFSOUTH Command post for a European met with such categorical US refusal; or that the US Sixth Fleet, theoretically to be transferred, in wartime, from US Naval Command Europe under NATO's jurisdiction, has never been placed under official NATO authority, even when supporting IFOR/SFOR NATO forces in Bosnia (which operated under AFSOUTH command) or during the Kosovo campaign (see Cogan 2003: 163-186). Indeed, why bother with transfer procedures and risk interference from European politicians when the gist of the planning and command runs, in any case, through a solely US chain. Of course, this American influence in and on NATO is not without its problems, as it was seen in one of the most well-known episodes of insubordination of recent years: the refusal of British General Sir Mike Jackson, in June 1999, to obey the order received from US General Wesley Clark (SACEUR) who, following instructions coming directly from the White House, wanted to engage Russian forces over the control of Pristina airport. 'I'm not going to start the Third World War for you' Jackson reportedly told General Clark during one heated exchange (Fitchett 1999; BBC 2000).

If the incident might help to explain the importance of the so-called 'caveats' (restrictions put in place by participating nations on the use of their forces under NATO command) in NATO operations, the problem which it highlights also applies to any form of integration under US 'leadership'. Be it the pooling of certain equipments under NATO's aegis or the common funding of Alliance operations, the logic is the same: the more one ties themselves within a framework where one does not have a real influence, the more one deprives themselves of a margin of manoeuvre to decide, to act and, in the final analysis, to exert a real influence.

\footnotetext{
${ }^{36}$ See, inter alia, President de Gaulle's press conferences, 5 September 1960 and 21 February 1966.

37 See, inter alia, President de Gaulle's press conference, 11 April 1961 and Foreign Minister M. Couve de Murville's interview à l'ORTF, 17 March 1966.
} 


\section{Autonomy}

The imperative of European autonomy would normally be considered self-evident; both for reasons of democratic legitimacy and strategic calculation, as well as for pragmatic long-term interests and elementary dignity. In the field of the ESDP itself, it is furthermore extremely difficult to explain why European defence, launched to confer credibility to the EU's foreign and security policy, would discredit itself by institutionalising its own subordination. This is all the more important given that Title $V$ Article 11 of the EU's current treaty states that the first objective of the EU's common foreign and security policy, in which ESDP is said to be 'included', is 'to safeguard the common values, fundamental interests, independence [author's stress] and integrity of the Union'. ${ }^{38}$ However, not only are we still waiting to see when these words will be translated into acts, but the question of even knowing whether they should be translated into acts one day, remains subject to debate.

The cause of this hesitation is as obvious as its absurdity. Once again, we are confronted with the fundamental divergences among EU Member States; above all, the model adopted and advocated by Great Britain and the one embodied and recommended by the French diplomacy. A vision usually referred to as the 'Greek temptation' and one that sees autonomy as a universal prerequisite.

As for the British model, its theoretical fundaments were already in place in the 1950s when 'the sentiment prevailing in Britain, expressed by such political figures as Harold Macmillan and by British pundits of the distinction of Alistair Buchan, was that the British would serve civilization as Greeks to the American Romans. In other words, Britain may have lost an empire but not the wisdom, as in the case of Greek slaves, to guide the powerful and relatively ignorant Americans, the Romans of the twentieth century' (Kaplan 2004: 11-12). Of course, this hope was, even with the less-than-noble connotation of the 'slave' precedent put aside, utterly naive and mistaken. As the exDirector of the Royal Institute of International Affairs observed when assessing Tony Blair's foreign policy record; 'Given the Byzantine complexity of Washington politics, it was always unrealistic to think that outside powers - however loyal - could expect to have much influence on the US decision-making process' (Bulmer-Thomas 2006). A former British diplomat and ex-chairman of the UK's joint intelligence committee went further in highlighting the internal dynamics of the 'special relationship'. According to Rodric Braithwaite (2003); 'American policymakers find them [the British] useful as spear carriers in the UN and NATO, and as reasonably competent military allies when it comes to a shooting war. From time to time they try to use the British as a potential Trojan horse, if European integration looks like being too successful'. Braithwaite's precisions concerning the military-related consequences of the British attitude could provide some food for thought to the zealous advocates of a European defence that would allegedly be 'complementary' to America: 'in anything like a real war they [British forces] will only operate as an integral part of a US force, under US command and serving US interests'. The verdict is without appeal: 'In contrast to the French, who preferred to plough a more lonely but independent furrow, co-operation with the Americans has robbed the British of much of their independence'.39

It is indeed the policy pursued by Paris which constitutes the perfect counter-example of the self-enslaving behaviour of British diplomacy. In connection with which French policy it is preferable to dissipate two misleading stereotypes. Contrary to the widespread clichés, the line followed by Paris has nothing to do with national(ist)

\footnotetext{
${ }^{38}$ Consolidated versions of the Treaty on European Union and of the Treaty establishing the European Community, Official Journal C321 E/1, 29 December 2006.

${ }^{39}$ Rodric Braithwaite was British ambassador in Moscow, and chairman of the joint intelligence committee (1992-1993).
} 
nostalgia, nor with any kind of mythic anti-Americanism. Quite the opposite, it is turned towards a resolutely European future and establishes the requirement of freedom of decision and action as an immutable axiom, with no need whatsoever for any circumstantial point of reference. ${ }^{40}$ Like Howorth (2007: 160) has observed, 'France is not "balancing" (either in hard or soft terms) against the US. She is pursuing her own agenda and that, as she sees it, of the European Union. To the extent to which this might, at one level - and at one level only - make life more complex for US policy preferences, then that's simply a fact of life." Indeed, within the European framework, France simply follows the principle that we do not share sovereignty in order to collectively lose it, but rather with the purpose of enhancing it. When this is impossible, due to resistance from other Member States, then the rule remains unchanged: 'in waiting for the sky to clear, France is pursuing, by her own means, that which a European and independent policy can and should be'. ${ }^{41}$

\section{Prospects}

A number of commentators expect from some near-time deadlines (EU and NATO separate but parallel operations in Afghanistan and Kosovo, one NATO summit due in 2008 and another one in 2009, marking the Alliance's $60^{\text {th }}$ anniversary, with a new US administration by then) the so-called normalisation of EU-NATO relations (Lidley-French 2007). In reality, the maximum which one can hope for, let alone the marketing effects and the cosmetic improvements which, without any doubt, will abound in this direction, is to see the deep tensions put on ice for one brief moment, so that they can arise in an even more conflictual form thereafter (see Vincze 2006e).

In fact, the accumulated grievances stem today from two basic sources. Added to the rancour related to the original situation of imbalance (reflected until the present day in NATO's still-decisive presence with its unchanged internal logic), comes the tensions associated with the junior partner's inevitable tendency towards emancipation (as illustrated by the launching of European defence).

With regard to the unequal partnership, as Charles A. Kupchan (2005: 152 \& 267) observed, 'despite all that has changed since 1949, and especially since 1989, Europe has remained dependent on the United States to manage its security' which is all the more significant because 'control over security matters is, after all, the decisive factor in setting the pecking order and determining who is in command'. Zbigniew Brzezinski (1997: 59) put it even more bluntly when he said, 'the brutal fact is that Western Europe, and increasingly also Central Europe, remains largely an American protectorate, with its allied states reminiscent of ancient vassals and tributaries'. From a US perspective rightly so, since ' $[A]$ politically powerful Europe, able to compete economically while militarily no longer dependent on the United States would inevitably contest American preeminence' and could confine its scope 'largely to the Pacific ocean' (Brezezinski 2004: 91).

Things are, nevertheless, bound to change. The latest report in the WEU Assembly on the subject of EU-NATO relations noted that: 'Europe's emancipation from NATO and the United States in the field of security and foreign policy is irreversible and growing. It is responding to general trends in public opinion and Europe's awareness of its responsibility to deal with world security problems' (Goerens 2006). Although the term 'awareness' could arguably be replaced by 'impossibility to continue to avoid facing the

\footnotetext{
${ }^{40}$ For a deeper analysis of these particular aspects of French foreign policy, see Vincze (2002).

${ }^{41}$ President de Gaulle's press conference, 23 July 1964.
} 
fact' and 'responsibility to deal' by 'the price of choosing not to', the basic observation is undoubtedly correct. As Kupchan (2006) observes it from the US side:

The Atlantic order is experiencing a systemic change (...) their [Europe's and America's] interests have returned to being separate, even if contingently convergent - precisely why transatlantic security institutions have been strained to a breaking point (...) This setback is neither a temporary aberration nor a passing byproduct of the policies of the Bush Administration. Rather, deeper changes in the geopolitical environment and America's domestic politics are at work; the Atlantic order will remain frayed regardless of which party holds power in Washington.

In the post-Cold War strategic context, both the original imbalance and the lengthy and wavering European emancipation process would be sufficient, each on its own, to poison and, with time, fatally undermine the transatlantic relationship. As long as the imbalance remains (with a Europe acquiescing to her dependence of the United States), any improvement in EU-NATO, as well as more broadly in transatlantic, relations can only be temporary and superficial. Under the present circumstances, the 'Other' is perceived on the two sides of the Atlantic either as a burden (free-rider or oppressing master), or as a rival (the 'challenger' versus the 'hegemon'), but generally both, burden and rival, at the same time. Instead of being able to act together like genuine partners (since this would only be possible between two sovereign parties, belonging more or less to the same category), Europe, dependent or disaggregated, is inapt to play her part. Her relations with the United States (both at the EU/collective and the national/bilateral level) have been poisoned throughout this last half-century by the inherent imbalance which means that one of the parties would always be able to leave the cooperation without its strategic potential being impaired, which is far from being the case for the other one. This tension-generating situation derives from European dependence; as long as this dependence lasts, it excludes any reciprocity and prohibits any genuine partnership.

Paradoxically, the only way out of this conundrum is the same that provokes, when the idea is evoked, immediate furore and controversy. It is for Europeans to assume their autonomy; a return to 'normalcy' so to speak (Kupchan 2006). This is the only way to replace the transatlantic relationship on a healthy - balanced, legitimate and thus sustainable - basis. The only way to achieve Euro-American cooperation in which the two parties take part freely, each one according to its own priorities and interests, liberated from the obligations linked to the position of the 'vassal' or that of the 'leader'. In other words, a cooperation based on choice, and not on a sense of constraint.

Jean Monnet, the 'father' of European integration and a strongly committed friend of the United States, wrote as early as in 1948 that 'the current situation in which our security depends on America cannot continue for a long time before it deteriorates (...) From "the stake" that we are now, will we become "associates", the masters of our own destiny? It is the question'. ${ }^{42}$ As we have seen, back in those immediate post-War years full non-dependence was rather unrealistic, but almost six decades have passed since then. The geopolitical conditions have already been radically transformed, and we are obviously far, very far, from witnessing the end of history. In view of the current and forthcoming reconfiguration of the international order, it might not be completely useless to recall another warning from the same Jean Monnet: 'The only choice we have

\footnotetext{
42 Jean Monnet's letter addressed to his friend René Mayer from Washington, 18 April 1948. Quoted in Roussel (1996: 486).
} 
is between changes in which we will be dragged into and changes which we will have been strong enough to want and to bring about'.43

\section{References}

Adams, G., Ben-Ari, G., Logsdon, J. and Williamson, R. (2004) Bridging the Gap: European C4ISR Capabilities and Transatlantic Interoperability, The George Washington University, October.

Albright, M.K. and Cohen, W.S. (2000) 'Get ESDI Right', Wall Street Journal Europe, 24 March 24.

Archick, K. (2005) 'The United States and Europe: Current Issues', Congressional Research Service Report for United States Congress, 10 June, available at: http://fpc.state.gov/documents/organization/48370.pdf

BBC (2000) 'Confrontation over Pristina airport', BBC News Online, 9 March, available at: http://news.bbc.co.uk/1/hi/world/europe/671495.stm

Braithwaite, R. (2003) 'End of the affair', Prospect Magazine No. 86, May.

Brzezinski, Z. (1997) The Grand Chessboard: American Primacy And Its Geostrategic Imperatives, New York: Basic Books.

Brzezinski, Z. (2004) The Choice: Global Domination or Global Leadership, New York: Basic Books.

Bulmer-Thomas, V. (2006) Blair's Foreign Policy and its Possible Successor(s), London: Chatham House

Burwell, F.G. (2006) 'NATO and the EU: Planning for the Future', EuroFuture, Autumn.

Chace, J. and Carr, C. (1988) America Invulnerable: The Quest for Absolute Security from 1812 to Star Wars, New York: Summit Books.

Cogan, C. (2003) French Negotiating Behaviour - dealing with La Grande Nation, Washington: United States Institute of Peace Press.

Cornish, P. (2006) 'EU and NATO: Co-operation or Competition?', European Parliament Directorate-General for External Policies of the Union, October.

Ellner, A. (2004) 'Le projet NFR-90 (frégate de l'OTAN pour les années 1990)' in J.P. Hébert and J. Hamiot (eds.), Histoire de la coopération européenne dans l'armement, CNRS Editions.

EC (1973) 'Declaration on European Identity, by the Heads of State or Government of the nine Member States of the European Community at the Copenhagen European Summit of 14 and 15 December 1973', in Bulletin of the European Communities. December, No 12, pp. 118-122.

EU (2007) ESDP Newsletter, No. 4, July, Brussels: Council of the European Union, available at:

http://www.consilium.europa.eu/ueDocs/cms Data/docs/pressData/en/esdp/953 28.pdf

Fitchett, J. (1999) 'Airport was Lost in Command Confusion: Faulty Allied Teamwork Helped Russian Dash', International Herald Tribune, 19 June, available at: http://www.iht.com/articles/1999/06/19/force.2.t 2.php

Friedman, T.L. (2002), 'The End of NATO? Europe had Better Catch Up', International Herald Tribune, 4 February.

Gellman, B. (1992) 'Keeping the U.S. First: Pentagon Would Preclude a Rival Superpower', The Washington Post, 11 March.

Goerens, C. (2006) 'NATO : transformation and strategic partnership with the EU', report submitted on behalf of the Political Committee of the WEU Assembly, 18 December, available at: $\quad$ http://www.assemblyweu.org/en/documents/sessions ordinaires/rpt/2006/1951.pdf?PHPSESSID=f313 $\underline{7 d 60}$

\footnotetext{
${ }^{43}$ Speech by Jean Monnet in Strasbourg, 12 May 1954.
} 
Hammarström, U. (2006) 'What sort of Defence Industry Do We Want?', EDA Bulletin, December.

Heisbourg, F. (1987) 'Can the Atlantic Alliance Last Out the Century?', International Affairs, Vol. 63 (2), Summer, pp. 413-423.

Hendrickson, R.C. (2007) 'The Miscalculation of NATO's Death', Parameters, Vol 37 (1), Spring, pp. 98-114

Hofmann, S. and Reynolds, C. (2007) 'EU-NATO Relations: Time to Thaw the "Frozen Conflict"', SWP Comments No. 12, June. German Institute for International and Security Affairs;

Howorth, J. (2000) 'European Integration and Defence: the Ultimate Challenge?', Chaillot Paper, No. 43, November.

Howorth, J. (2003) 'Saint Malo plus five: an interim assessment of ESDP', Notre Europe Policy Papers No. 7, November.

Howorth, J. (2005) 'The Euro-Atlantic Security Dilemma: France, Britain and the ESDP', Journal of Transatlantic Studies, Vol. 3 (1), pp.39-54.

Howorth, J. (2007) Security and Defence Policy in the European Union. Houndsmill: Palgrave MacMillan.

Howorth, J. and Keeler, J.T.S. (2004) 'The EU, NATO and the Quest for European Autonomy', in J. Howorth and J.T.S. Keeler (eds.), Defending Europe: The EU, NATO and the Quest for European Autonomy. Houndsmill: Palgrave MacMillan. pp.3-24.

Kaplan, L.S. (2004) NATO Divided, NATO United: the Evolution of the Atlantic Alliance, Westport, CT: Praeger Publishers.

Kaplan, R.D. (2005) 'How We Would Fight China', The Atlantic Monthly, June, available at: http://www.theatlantic.com/doc/200506/kaplan

Keohane, D. (2006) 'Unblocking EU-NATO Co-operation', CER Bulletin Issue 48, Centre for European Reform, June/July, available at: http://www.cer.org.uk/articles/issue48.html

Kupchan, C.A. (2005) The End of the American Era, Vintage Books

Kupchan, C.A. (2006) 'The Fourth Age: The Next Era in Transatlantic Relations', National Interest, Sept/Oct. pp.77-83.

Larrabee, S. (2004) ESDP and NATO, Assuring Complementarity, RAND Corporation.

Layne, C. (2006) The Peace of Illusions - American Grand Strategy from 1940 to the Present, New York: Cornell University Press.

Lidley-French, J. (2007) 'Flexible Effect: EU-NATO Relations in a New Strategic Age', speech at the Bundestag, Berlin 22-23 April.

Masson, H. (2006) L'Union européenne et l'expérience dans les Balkans (1991-2006), Fondation pour la Recherche Stratégique, September.

Leo Michel, 'NATO and the EU, Stop the Minuet; it's Time to Tango', EuroFuture, 2004/winter, pp. 88-91, avaiable at:

http://www.ndu.edu/inss/Repository/Outside_Publications/Michel/Michel_EuroF uture Winter2004.pdf

Minniti, M. (2005) 'NATO-EU security co-operation', [176 PCNP 05 E], Report to the NATO Parliamentary Assembly 2005 Annual Session, available at:

http://www.nato-pa.int/Default.asp?SHORTCUT $=675$

Monaco, A. and Gourlay, C. (2005) 'Supporting the African Union in Darfur: a test for the EU-NATO partnership', European Security Review No. 26, June, pp.3-5, available at: http://www.isis-europe.org/ESR26-Print\%20Friendly.pdf

Patten, C. (2005) Not Quite the Diplomat - Home Truths about World Affairs, London: Penguin.

Pullinger, S. (ed.) (2006) Developing EU Civil Military Co-ordination: the Role of the new Civilian Military Cell, Joint Report by ISIS Europe and CeMiSS, June.

Rodman , P.W. (1999) 'European Common Foreign, Security, and Defense Policies Implications for the United States and the Atlantic Alliance', Testimony Before the Committee on International Relations, United States House of Representatives, 10 
November, available at:

http://www.nixoncenter.org/publications/testimony/11 10 99Europe.htm

Roussel, E. (1996) Jean Monnet, Paris: Fayard.

Schake, K. (2003) 'The United States, ESDP and Constructive Duplication', in J. Howorth and J.T.S. Keeler (eds.), Defending Europe: The EU, NATO and the Quest for European Autonomy. Houndsmill: Palgrave MacMillan. pp.107-132.

Shimkus, J. (2007) 'NATO-EU Operational Cooperation' [039 DSCTC 07 E], Report to the NATO Parliamentary Assembly's 2007 spring session, available at:

http://www.nato-pa.int/Default.asp?SHORTCUT=1168

Sloan, S.R. (2000) 'The United States and European Defence', Chaillot Paper, No. 39, April.

Smith, R. (2005) 'Europe is the best weapon to win both war and peace', European Voice, 15 December 2005.

Tigner, B. (2005) 'EDA May Scrutinize Trans-Atlantic Defense Trade Flow', DefenseNews, No. 3 June.

Van Oudenaren, J. (2003) Status Quo vs. Revisionist Policies in Transatlantic Relations, Presentation at the Transatlantic Roundtable, July 17-18, Brussels.

Vincze, H. (2002) 'France: From Great Power Illusions to the "Europeanization" of Ambitions', Foreign Policy Review Vol. I (2).

Vincze, H. (2003) Beyond Symbolism: the EU's First Military Operation Seen in its Context, Die Deutsche Gesellschaft für Auswärtige Politik, July, available at: http://www.weltpolitik.net.

Vincze, H. (2006a) 'The European Union's foreign, security and defence policy - in a nutshell', Presentation at the Central European Conference, Hungary, 8 April 2006, available at: http://www.hajnalka-vincze.com/Publications/147.

Vincze H. (2006b) 'Becoming flexible to keep it together: the logic and the pitfalls behind the concept of differentiated integration', The Federalist, 48 (1), pp. 55-63.

Vincze, H. (2006c) 'Article 296: Friend or Foe?, EuroFuture, Winter 2006

Vincze, H. (2006d) 'L'article 296 du TICE: obstacle ou garde-fou?', Défense \& Stratégie, No. 18 , October.

Vincze, H. (2006e) 'Towards the demystification of the transatlantic relationship', in H. Vincze (ed.) The Transatlantic Debate, Budapest: Zrínyi Kiadó. French version available at: http://www.armees.com/Vers-la-demystification-de-la-relationtransatlantique, $1146 . \mathrm{html}$

WEU (1987) 'The Hague Platform on European Security Interests, adopted by the WEU Council of Ministers', 27 October 1987 